\title{
FOXA3 wt Allele
}

National Cancer Institute

\section{Source}

National Cancer Institute. FOXA3 wt Allele. NCI Thesaurus. Code C102508.

Human FOXA3 wild-type allele is located within 19q13.2-q13.4 and is approximately $10 \mathrm{~kb}$ in length. This allele, which encodes hepatocyte nuclear factor 3-gamma protein, is involved in transcriptional activation. 